\title{
Evaluation of the Efficacy of Amarsundari Vati (Tablet) and Caroverine hydrochloride capsule in the Management of Cochlear Synaptic Tinnitus
}

\author{
*Waghmare Gangaprasad Anantrao \\ Department of Shalakya Tantra (ENT), Assistant Professor \& ENT Consultant, India
}

Submission: April 04, 2017; Published: April 12, 2017

*Corresponding author: Waghmare Gangaprasad Anantrao, Department of shalakya Tantra (ENT), Assistant Professor \& ENT Consultant, Mumbai-400002, Maharashtra, India, Tel: 09096566633, Email: drgw007@gmail.com

Abstract

With the aim to evaluate the efficacy of Amarsundari Vati (Tablet) and Caroverine Hydrochloride capsule in the management of Cochlear Synaptic Tinnitus, a Single blind randomized clinical study was done. For the clinical study of Cochlear Synaptic Tinnitus, 30 subjects was selected and studied. Subject's fulfilling the criteria of diagnosis was studied irrespective of their religion, caste, sex and socio-economic status from shalakya-tantra (ENT) department of the institute after thorough scrutiny and proper consent in his/her language.

The Subject's having age between 40-70 yrs was selected for the clinical Study. Detail history of the patient were elicited, pathological investigation including Hb, TLC, DLC, RBS and required radiological investigation were done in a diagnostic Centre. The examination of the Ear Audiometry, Vestibular examination, Otoscopic examination is also carried out with the help of modern viewing techniques. After observation and analytical study with the help of Wilcoxon sign rank test and Man-whiteny test it was concluded that in Cochlear Synaptic Tinnitus treatment with Amarsundari Vati (Tablet) shows more effective Result in relieving sign and symptoms than Caroverine Hydrochloride Capsule.

Keywords: Amarsundari Vati (Tablet); Caroverine Hydrochloride Capsule; Cochlear Synaptic Tinnitus; Shalakya-tantra; Audiometry; Vertigo, Deafness; Ringing in ear; Noise in ear; Headache

\section{Introduction}

Tinnitus is the Perception of sound in the absence of an external sound source and in most cases occurs with Hearing loss. Two main cochlear pathologies could be at the origin of tinnitus, research is providing more \& more findings to support the first hypothesis, relating tinnitus to an "epileptic" reaction in the Auditory nerve (Malfunction of the glutamatergic synapse between inner hair cells \& Auditory Nerve). Cochlear Synaptic Tinnitus is one among the many socio-medical problems [1]. Most studies indicate the prevalence in adults as falling within range of $10 \%$ to $15 \%$, with greater prevalence at higher ages [2]. Tinnitus associated with Hearing impairment among elderly people is a major issue and a person with Tinnitus become socially isolated; this scenario can make them feel frustrated, lonely and depressed [3]. Tinnitus can interfere with person's ability to hear, work, and perform daily activities.

One study showed that $33 \%$ of persons being treated for Tinnitus reported that it disrupted their sleep. According to WHO nearly 1.2 billion people will be over the age of $60 \mathrm{yr}$ consequently the prevalence of age related auditory and vestibular dysfunction will increase by 2025 [4]. Cochlear Synaptic Tinnitus can be improved by using the Maskers, but it may not be a perfect solution for all [5]. In classics of Ayurveda this ailment has been described as karnanaad under the heading of ear diseases [6]. Vatahar Chikitsa (Neuroprotective Treatment) is one of the major treatments for ear diseases explained in classics [7]. Clinical observation has shown its effectiveness in the management of Cochlear Synaptic Tinnitus [8].

\section{Objectives}

a. To study efficacy of Amarsundari Vati (Tablet) in Cochlear Synaptic Tinnitus.

b. To study efficacy of Caroverine Hydrochloride Capsule in Cochlear Synaptic Tinnitus

c. Comparing the efficacy of Amarsundari Vati (Tablet) and Caroverine Hydrochloride Capsule in Cochlear Synaptic Tinnitus. 


\section{Hypothesis}

a) H0-Amarsundari Vati (Tablet) and Caroverine Hydrochloride Capsule do not have any effect on Cochlear Synaptic Tinnitus.

b) H1-Amarsundari Vati (Tablet) and Caroverine Hydrochloride Capsule do have any effect on Cochlear Synaptic Tinnitus.

\section{Material and Methods}

\section{Study Design}

Simple random sampling technique comparative clinical study [9]. Patient will be selected from the OPD of department of Shalakya Tantra (ENT), after thorough scrutiny and proper consent.

\section{Composition of trial drug [10] (Tables 1\& 2)}

Table 1: Amarsundari Vati (Tablet) Ref. Ayurveda Saar-Sangraha.

\begin{tabular}{|c|c|c|c|c|c|}
\hline S. No & Sanskrit Name & Botanical Name & Family & Part Used & Proportion \\
\hline 1 & Parad & Mercury & - & - & 1 \\
\hline 2 & Gandhak & Sulphur & - & - & 1 \\
\hline 3 & Lohabhasma & Iron & - & Fruit & 1 \\
\hline 4 & Amalaki & Embelicaofficinalis & Euphorbiaceae & Fruit & 1 \\
\hline 5 & Haritaki & Terminaliachebula & Combrataceae & Fruit & 1 \\
\hline 6 & Bibhitak & Terminaliabellirica & Combrataceae & Tuber & 1 \\
\hline 7 & Sunthi & Zingiberofficinale & Zingiberaceae & Fruit & Root \\
\hline 8 & Marich & Piper nigrum & Piperaceae & Root & 1 \\
\hline 10 & Pippali & Piper longum & Piperaceae & - & 1 \\
\hline 11 & Vatsanabh & Aconitum ferox & Rananculaceae & - & 2 \\
\hline
\end{tabular}

Table 2: Tb.Caroverine Hydrochloride.

\begin{tabular}{|c|c|c|}
\hline S. No & Ingredient & Composition (mg) \\
\hline 1. & Caroverine Hydrochloride & $20 \mathrm{mg}$ \\
\hline & Equivalent to Caroverine & q.s. \\
\hline
\end{tabular}

\section{Sample size:}

Group $\mathrm{A}=\mathrm{N} 1=15$

Group B=N2= 15

Total $=30$

\section{Grouping: 2 groups}

i. Group A: Treatment with Amarsundari Vati (Tablet).

ii. Group B: Treatment with Caroverine Hydrochloride Capsule.

\section{Posology}

Group A - Oral treatment with Amarsundari Vati (Tablet)

Group B- Oral treatment with Caroverine Hydrochloride Capsule.

\section{Treatment Duration}

Group A - Oral treatment with Amarsundari Vati (Tablet) -2 Tablets 2 times a Day for 60 days.
Group B - Oral treatment with Caroverine Hydrochloride Capsule- 2 Capsule 2 times a Day for 60 days.

Intervention (Table 3)

Table 3: Intervention.

\begin{tabular}{|c|c|c|}
\hline Grouping & Group A & Group B \\
\hline Sample size & 15 & 15 \\
\hline Intervention & $\begin{array}{c}\text { Amarsundari Vati } \\
\text { Tablet) (2 Tablets 2 } \\
\text { times a Day ) }\end{array}$ & $\begin{array}{c}\text { Caroverine } \\
\text { Hydrochloride } \\
\text { Capsule (2 Capsule 2 } \\
\text { times a Day ) }\end{array}$ \\
\hline Treatment duration & 60 days & 60 days \\
\hline Follow up & After 7 days & After 7 days \\
\hline
\end{tabular}

\section{Criteria for assessment}

\section{1) Criteria of inclusion}

a) Patient having Clinical Signs \& Symptoms of Cochlear Synaptic Tinnitus.(Ringing/whistling/roaring sound in Ear)

b) Audiometric findings. 
c) Age group between 40 to 70 years of either gender having Clinical Signs \& Symptoms of Cochlear Synaptic Tinnitus.

\section{2) Criteria of exclusion}

a) Subjects suffering from middle ear infectious diseases.

b) Patient having profound hearing loss i.e. hearing loss above $90 \mathrm{db}$.

c) Patient having perforation to Tympanic Membrane.

d) Patients having Hypersensitivity to Caroverine.

e) Patients having Acute Stomach \& Intestinal Ulcer.

\section{3) Criteria for evaluation}

Assessment will be done on the basis of improvement in signs \& Symptoms of Cochlear Synaptic Tinnitus and from Subjective \& Objective parameters of data.

\section{4) Subjective Criteria}

a. Peripheral Vertigo - Alexander's Law (Table 4)

Table 4: Peripheral Vertigo- Alexander's Law.

\begin{tabular}{|c|c|}
\hline Grades & Vertigo \\
\hline $1^{\text {st }}$ Degree & $\begin{array}{c}\text { Present only when subject looks in the direction of } \\
\text { fast phase }\end{array}$ \\
\hline $2^{\text {nd }}$ Degree & Present when subject looks straight ahead \\
\hline $3^{\text {rd }}$ Degree & $\begin{array}{c}\text { Present even when subject looks in the direction of } \\
\text { slow phase }\end{array}$ \\
\hline
\end{tabular}

\section{5) Objective criteria}

a. Cochlear Synaptic Tinnitus (Ringing in ear) - Obtain by hearing thresholds, loudness , pitch , and masking curves of Cochlear Synaptic Tinnitus, computer programs enable all of these measures to be obtained in a single session

b. Deafness-Good-man's rule of hearing loss for deafness.

i. $\quad 0-25 \mathrm{db}$ - Normal hearing

ii. $\quad 26-40 \mathrm{db}-$ mild hearing loss

iii. $\quad 41-55 \mathrm{db}$ - moderate hearing loss

iv. $56-70 \mathrm{db}$ - moderate to severe hearing loss

v. 71-90db-severe hearing loss

vi. $>90 \mathrm{db}$ - profound hearing loss

\section{6) Investigation}

a. Pathological
i. $\quad \mathrm{CBC}$
ii. $\quad$ ESR
iii. RBS
iv. Sr. Creatine

\section{v. Sr. Uric acid}

\section{b. Clinical Investigation}
i. Rinne's test.
ii. Weber's test.
iii. $\mathrm{ABC}$ test.
iv. Audiometry.
v. Tympanometry.
vi. Otoacousticemmision Test.
vii. Auditory brain stem response.
viii. Electrocochleography.
ix. Neuropsychological Test.

\section{c. Radiological}

a) X-Ray Mastoid Bone-Schuller's View.

b) CT / MRI -Temporal Bone.

\section{Results and Discussion}

In the Group A the Mean Vertigo was observe to be 1.625 before treatment that reduced to 1.558 after treatment ( $p$ value $>0.05$ ), the Mean Cochlear Synaptic Tinnitus was observe to be 2.5 before treatment that reduced to 0.6652 after treatment ( $p$ value $<0.05$ ), the Mean Deafness was observe to be 2.467 before treatment that reduced to 0.7089 after treatment ( $p$ value $<0.05$ ). In the Group B the Mean Vertigo was observe to be 1.500 before treatment that reduced to 1.400 after treatment ( $p$ value $>0.05$ ), the Mean Cochlear Synaptic Tinnitus was observe to be 2.333 before treatment that reduced to 1.1258 after treatment ( $p$ value $<0.05$ ), the Mean Deafness was observe to be 2.300 before treatment that reduced to 1.067 after treatment ( $p$ value $<0.05$ ).

To examine either the groups differs from each other significantly or not, further data are treated by Mann whiteny $\mathrm{U}$ score test. For Vertigo the mean difference in value in group $\mathrm{A}$ was 0.06667 while that in Group B was 0.1000 ( $p$ value >0.05). For Cochlear Synaptic Tinnitus the mean difference in value in group A was 1.7658 while that in Group B was 0.9667 (p value $<0.05$ ). For Deafness the mean difference in value in group $A$ was 1.767 while that in Group B was 1.233(p value $<0.05$ ).

\section{Conclusion}

In this series, 30 patients of Cochlear Synaptic Tinnitus were studied, no any difference in sex ratio is found i.e. both male to female ratio is equal, $63.33 \%$ patients belonging to Hindu religion, maximum number of patient are educated up to mid school and high school i.e. $26.66 \%$ each. $70 \%$ of patients are from lower socio-economic level, $60 \%$ patient were suffering from Cochlear Synaptic Tinnitus since more than 5 yrs, 71.66\% patient were having kaphavatajprakriti, 38.33\% patient were having mandagni, $68.33 \%$ patients were taking sheet gunatmaka 
Ahar while $61.66 \%$ patient were taking rukshagunatmak Ahar, $48.33 \%$ patient were taking dominant katurasatmaka Ahar and $73.33 \%$ patients were taking mixed type of diet. In this study $100 \%$ patients of both groups were having vata dosh dushti while $75 \%$ patient were having kapha dosh dushti,100\% patients of both groups were having Rasa dushyadushti while Mansa and Majjadushyadushti were $80 \%$ and71.66\% respectively. $25 \%$ patients were living in Noisy residential area, $18.33 \%$ patients were doing labor work and 35\% patients were having history of addictions. After doing inference confidently by Wilcoxon Sign Rank Test, it is found that in group A except for Vertigo difference between before treatment and after treatment are statistically highly significant for Cochlear Synaptic Tinnitus \& Deafness.

Also in group B treatment with Caroverine Hydrochloride Capsule are effective in relieving symptoms of Cochlear Synaptic Tinnitus except for symptom Vertigo. After doing Mann-Whiteny $\mathrm{U}$ Test to examine difference between effects of treatment in both groups it is found that for Cochlear Synaptic Tinnitus\& Deafness the inference is highly significant. I.e. for above symptoms Group A shows better result than Group B. But for Vertigo the inference is in-significant. The property of Amarsundarivati is acts Oto- neuroprotective .It also has potent antioxidant effect .Amarsundari vati is acidic in nature, excess of hydrogen ions are useful for capillary circulation. Increased $\mathrm{H}+$ ions concentration dilate the capillary. As Amarsundarivatiis having excess of $\mathrm{H}+$ ions concentration it causes dilatation of capillary. Amarsundarivati produces vasodilatation in the locality. In neurology this reflex is known as Axon reflex. From the above discussion, it is clear that
Subjects having clinical features of Cochlear Synaptic Tinnitus are more significantly reduced in Group A than Group B which itself prove that treatment with Amarsundari Vati (Tablet) is better than treatment with Caroverine Hydrochloride Capsule in Cochlear Synaptic Tinnitus.

\section{References}

1. Alxender Rosinkin, VT Palchun, NL Voznesenky (2013) Diseases of Ear, Nose and throat, MIR Publishers, Moscow, Russia.

2. Venimadhav shastri Joshi (1968) Ayurvediya Shabdakosha, Maharashtra Rajyasahitya and Sanskruti Mandal. Mumbai, India.

3. KB Bhargava (2000) Short text book of ENT Diseases. Usha Publications, Gopal bhavan, Tagore Road, Mumbai, India.

4. Simson Hall, Barnard H, Colman Churchill (1981) Diseases of Ear, Nose and throat. Livingstone, Robert Stevension, Edinburgh, Scotland.

5. PL Dhingra (1998) Diseases of Ear, Nose and throat. BI Churchill Livingstone, Janapath, New Delhi, India.

6. (1994) Yadavaji Trikamji Acharya, Dalhan, Nibandha Sangraha comm. on Sushruta, Chaukhambha Sanskrit Sansthan, Varanasi, India.

7. (1970) Kaviraj Ambikadatta Shastri Vidyotini Hindi Comm Edited by shri Rajeshwar Datta Shastri Bhaishajya Ratnavali- Choukhambha Sanskrit Sansthan, Varanasi, India.

8. Yadavjitrikamjiaachrya, Ayurned Deepika (1941) Chakrapani data comm. on -Charak Samhita, Nirnaya Sagar Press, Mumbai, India.

9. B K Mahajan (1999) Methods in Biostatistics, Jaypee Brothers Medical Publishers Pvt. Ltd. Dariyaganj, New Delhi, India.

10. Acharya Priyawat Sharma, Dravya Guna Vignyana, Published By Chaukhambha Bharti Acadamy, Varanasi, India.

Your next submission with Juniper Publishers will reach you the below assets

- Quality Editorial service

- Swift Peer Review

- Reprints availability

- E-prints Service

- Manuscript Podcast for convenient understanding

- Global attainment for your research

- Manuscript accessibility in different formats ( Pdf, E-pub, Full Text, Audio)

- Unceasing customer service

Track the below URL for one-step submission https://juniperpublishers.com/online-submission.php 